\title{
Use of Social Cognitive Theory to Assess Salient Clinical Research in Chronic Disease Self-Management for Older Adults: An Integrative Review
}

\author{
Kimberly Sell1', Elaine Amella1, Martina Mueller'1, Jeannette Andrews², Joy Wachs ${ }^{3}$ \\ ${ }^{1}$ Medical University of South Carolina, Charleston, USA \\ ${ }^{2}$ University of South Carolina, Columbia, USA \\ ${ }^{3}$ East Tennessee State University, Johnson City, USA \\ Email: sell@etsu.edu, amellaej@musc.edu, muellerm@musc.edu, \\ JANDREWS@mailbox.sc.edu,WACHS@mail.etsu.edu
}

Received 26 January 2016; accepted 21 March 2016; published 24 March 2016

Copyright @ 2016 by authors and Scientific Research Publishing Inc.

This work is licensed under the Creative Commons Attribution International License (CC BY).

http://creativecommons.org/licenses/by/4.0/

(c) (i) Open Access

\begin{abstract}
The purpose of this integrative review is to evaluate research pertaining to self-management programs for older adults with chronic diseases using Albert Bandura's Social Cognitive Theory (SCT) for behavior change. The focus is application of the SCT domains to self-management programs. The exploration of the current chronic disease self-management research provides an understanding of the Social Cognitive Theory concepts studied in interventional self-management research. The integrative review explicated two areas related to the theory in need of further research. First, social support has not been thoroughly explored as a mechanism for enhancing self-management interventions. Second, moral disengagement was not identified as a focus within chronic disease research raising the question about the impact of moral disengagement on longterm adherence and behavior change.
\end{abstract}

\section{Keywords}

Social Cognitive Theory, Self-Management, Chronic Disease, and Older Adults, Integrative Review, Social Determinants of Health

\section{Introduction}

Chronic disease is a universal problem of epidemic proportions [1]. In 2008, the World Health Organization

How to cite this paper: Sell, K., Amella, E., Mueller, M., Andrews, J. and Wachs, J. (2016) Use of Social Cognitive Theory to Assess Salient Clinical Research in Chronic Disease Self-Management for Older Adults: An Integrative Review. Open Journal of Nursing, 6, 213-228. http://dx.doi.org/10.4236/ojn.2016.63022 
(WHO) estimated that of total deaths worldwide, 63\% were due to non-communicable diseases [2]. Premature death in those under 60 accounted for $25 \%$ of mortality; the majority of deaths were older adults with chronic diseases. Of those deaths worldwide, $80 \%$ of the individuals had significant risk factors [2] that could have responded to preventive interventions and decreased the likelihood of death.

In developed countries, deaths from chronic disease is a known phenomenon, but the significant increase of deaths from chronic disease in developing countries represents a change in global health [2]. In the United States the mortality rate for older adults living with chronic disease is increased, with chronic disease being the number one cause of death among older adults [3]. This constantly increasing level of illness creates a need for a worldwide focus on improving healthcare resources to address the spectrum of chronic disease, particularly in fostering self-care and delivering home care [4]. With poorer outcomes, increasing incidences of chronic disease, and growing demands on healthcare services, clearly chronic disease is a universal problem that requires aggressive action to decrease mortality [4]. Identifying prevention and health maintenance initiatives with specific emphasis on older adults who demonstrate the highest burden of disease is a crucial endeavor for all countries.

One strategy that is increasingly studied in chronic disease research is self-management [5]. In short-term studies, successful implementation of self-management programs has been linked to improved health outcomes, while ineffective use of self-management has correlated with increased mortality and decreased quality of life [5]. Self-management is a process through which the client learns to incorporate the skills and knowledge to provide self-care and allows the client to be an active participant in the care process [5] [6]. The individual is encouraged to actively communicate with the healthcare team to improve health outcomes [7]. Self-management programs teach participants information and skills related to their chronic disease to increase their self-efficacy. The belief that one can be successful in reaching set goals when using the knowledge and skills one has learned to manage his or her chronic diseases defines self-efficacy [8]. Self-efficacy is a component of Social Cognitive Theory that delineates the process of adult learning in behavior change [9]. Although research outcomes have demonstrated short-term improvement by increasing self-efficacy in self-management, long-term adherence has not been confirmed [10] [11], thus, current research should be evaluated using all domains of the Social Cognitive Theory to help identify possible avenues to improve self-management adherence.

This integrative review assessed the state of the science regarding self-management of chronic disease by older adults applying the domains of the Social Cognitive Theory to current research as a framework for behavior change and evaluating current research of self-management programs specific to older adults with emphasis on social determinants (e.g. race, gender, education, and geographic location). The purpose of the integrative review was to explicate gaps in the literature and define implications for future nursing research.

\section{Background/Significance}

Chronic disease is an incurable condition that lasts longer than 3 months [12]. Chronic disease is not confined to one specific age, sex, culture, or economic status. Living with a chronic disease has been linked to increased disability and decreased quality of life [5]. Co-morbidities have been shown to increase with age and therefore increase the impact on the older adult [13]. The projected increase in disability due to chronic disease among United States residents is expected to rise $350 \%$ by 2040 [14]. Global projections also indicate increasing disability [15]. Increasing disability and decreasing quality of life in those with chronic disease will directly impact the healthcare system.

The cost of treating individuals who need more healthcare visits, services, and medications will increase the pressure on health programs and resources. Currently, Medicare spending is expected to outpace private health insurance spending by 2020, consistent with the increased enrollment of the baby boomer population [16]. When all of the variables are viewed together, taking into consideration increasing costs, chronic disease, and at risk older adults, the need for developing innovative and cost-effective strategies to decrease the burden of chronic disease care should be increasingly emphasized in health care research.

The inclusion of self-management in several government initiatives demonstrates the importance of selfmanagement in addressing the impending healthcare crisis. The Affordable Care Act [8], the U.S. Department of Health and Human Services Initiative on Multiple Chronic Conditions [17], and the nationally sponsored Healthy People 2020 initiative [18] recommend the inclusion of chronic disease self-management in the treatment of chronic disease. Recognizing the global implications of chronic disease, the WHO has published recommendations reflecting emphasis on prevention, self-care, and home care for those with chronic diseases [4] 
[19]. Each of these initiatives seeks to improve health outcomes and reduce risk factors for complications of chronic diseases through a variety of innovative mechanisms such as self-management [4] [8] [20] [21].

As health care studies have evolved, self-management, self-monitoring, and self-care have been used interchangeably in the literature. Initially, the concept of self-management was viewed by scholars as "monitoring and evaluating one's behavior followed by reinforcing improvements in one’s performance" (Hughes \& Lloyd, 1993, p. 409). Today, the concept of self-management has expanded to include the ability of individuals to adhere to a plan of care based upon specific needs related to the illness [22]. For the purpose of this integrative review, self-management is the individual's ability to incorporate self-care and self-monitoring strategies into a collaborative relationship with healthcare professionals and support systems to improve health outcomes [23].

\section{Theoretical Framework}

Bandura noted that the Social Cognitive Theory (SCT) "provides both predictors and principles on how to inform, enable, guide, and motivate people to adapt habits that promote health and reduce those [habits] that impair it” (Bandura, 2004, p. 146). The theory introduces a method of changing behavior that, unlike other change theories, uniquely incorporates a mechanism to facilitate the change. For health behavior change to succeed several moderators must be recognized as potential facilitators or barriers to success. These moderators include level of self-efficacy, the symbiotic relationship between the environment and the individual, and quality and presence of social influences [9].

The SCT encompasses a broad spectrum of characteristics, such asgoal setting, barriers to successful selfmanagement, and beliefs about behavior change, affecting the ability of the individual to change [9]. In a behavior change these key concepts, reciprocal determinism, outcome expectations, observational learning, incentive motivation, facilitation, and moral disengagement are incorporated to maximize success [8].

For the purpose of this analysis, these concepts will be grouped into five domains: psychological determinants of behavior in which outcomes and self-efficacy are linked [8]; learning through observation in which role modeling and motivation are used; environmental determinants of behavior that focus on the interaction of the environment, society, and the individual; self-regulation through self-monitoring, feedback, and goal setting; and moral disengagement in which the perception of the individual toward the existing behavior can alter the change process [8] [24]. By evaluating current research for the use of these core concepts, it is possible to identify gaps in self-management research using the SCT domains and determining whether incorporation of these domains in future studies might improve self-management.

\section{Design}

For this integrative review, the framework of Whittemore and Knafl (2005) was chosen and found to be beneficial in developing a comprehensive understanding of the results of empirical studies in the field of self-management. The integrative review framework facilitated the exploration of the phenomenon of self-management with emphasis on core concepts of SCT and identified social determinants of health. The integrative review design provided the framework to identify the number of times specific concepts, specific chronic diseases were studied, and to analyze current research findings to identify gaps in the literature. The concepts identified as gaps in the literature are potential avenues for future research.

\section{Key Concepts}

In order to evaluate each manuscript, several key concepts from the Social Cognitive Theory were used in the integrative review. These concepts were psychological determinants, observational learning, environmental determinants, self-regulation, and moral disengagement.

\subsection{Psychological Determinants}

Two concepts in the domain of psychological determinants of behavior change are self-efficacy and outcome expectations. Self-efficacy is defined as the beliefs of individuals in their abilities to successfully create change. Self-efficacy is relevant to both individuals' actions and the combined beliefs of group behavior change [25]. Outcome expectations also affect the level of self-efficacy. Individuals are more likely to engage in health behavior activities if they believe the anticipated outcomes will be beneficial and that outcomes can be achieved [8] [25]. 


\subsection{Observational Learning}

Observational learning is an individual's ability to observe a modeled behavior (Bandura, 1986) and motivation to reproduce the behavior. Observational learning is most effective when learners perceive that role models are like them (Glanz et al., 2008). This notion would indicate that in self-management learners are more likely to incorporate new behaviors if the role models were similar to them in characteristics and managing a chronic disease.

\subsection{Environmental Determinants}

SCT also recognizes the impact the environment and personal factors, such as attitude, have on an individual as well as the effect the individual has on the environment. Reciprocal determinism is the three-way (triadic) interaction between these variables [8] [24]. The concept of reciprocal determinism supports the need to analyze the constantly changing process in which the individual, social factors and the environment impact the type of reaction individuals might have in a given situation [23].

\subsection{Self-Regulation}

Self-regulation is the ability to manage oneself [8] using a concrete, organized approach to goal attainment. This concept involves several necessary individual characteristics including the capacity to: 1) self-monitor behavior changes; 2) set goals towards achieving results; 3) provide feedback concerning progression [8] [24]; 4) reward success; 5) instruct self on the behaviors being performed; 6) and seek external support [8].

\subsection{Moral Disengagement}

The final concept within SCT is moral disengagement, the incorporation of an internal moral standard into self-regulation [8]. Individuals could argue that negative health behaviors are not harmful to anyone, including themselves [8]. An example would be a smoker stating that second hand smoke does not hurt anyone. In that case, impetus for change is absent and motivation to improve health behaviors is not a priority. An assessment of clients' moral reasoning is essential to understanding their desire either to make changes or to continue harmful behaviors.

\section{Methods}

Inclusion and exclusion criteria were established based upon the purpose of the integrative review. Articles were included for review if they were written in English and researchers had a) studied samples of older adults (65+) or samples of older adults and middle aged adults with a mean sample age of 65 or older; b) studied samples that included patients with chronic disease; and c) focused on self-management programs. All chronic diseases were accepted in the inclusion criteria so that a fuller idea of what disease states had been studied could be evaluated. With the initial application of inclusion criteria, a sufficient number of articles focusing on adults over the age of 65 could not be obtained; therefore, a second search was carried out for participants with a mean age of 60 years or older. When the second search did not yield sufficient samples, a third search with the age of 55 years or greater was used to complete the integrative review. Initial limitations of studies published within the last 10 years was used, but this also significantly limited the sample size. As this demonstrates a lack of research in older adults, the time limit was opened and manuscripts were accepted consistent with the initial inception of the Chronic Disease Self-Management Program. Choosing this approach allowed for establishing the state of the science of chronic disease self-management as it applies specifically to older adults.

Studies that were unpublished such as dissertations, conference proceedings, and manuscripts that did not provide empirical data concerning the implementation of self-management programs were excluded from the integrative review.

\subsection{Search Procedure}

A search of the literature was guided by the integrative review purpose as well as the exploratory questions. The process of reviewing literature included a bibliographic search of databases. The search was initially completed in January 2012 and updated in April 2013. The databases that were exhaustively searched included the Cumu- 
lative Index to Nursing and Allied Health Literature (CINAHL), Ovid/ MEDLINE, PsychINFO, and Google Scholar. During the Ovid/MEDLINE search, the Medical Subject Headings (MeSH) terms used were self-management, self-care, self-monitoring, chronic disease, and chronic illness. A publishing time limit was not set.

The same terms were used for a search of CINAHL, Google Scholar, and PsychINFO databases. The search process yielded a wide variety of articles $(n=1319)$ about self-management or self-control. The remaining studies were reviewed by reading individual abstracts for relevance. For those with no abstract, the manuscripts were read to determine pertinence to the integrative review. The inclusion and exclusion criteria were applied and the remaining studies were reviewed $(n=22)$. The ancestry method of reviewing article citations, which involved the review of manuscript citations for sources relevant to the review purpose, was employed to identify potential additional sources for the integrative review [26]. Ancestry searching did not result in additional articles. After completion of the search process, a total of 22 articles were identified that related to chronic disease self-management among those 55 years and older.

\subsection{Sample}

The studies included in the integrative review are displayed in Appendix 1. The type of research used in the studies was determined by evaluating the level of evidence included in the integrative review. The specific research methods in the sample included randomized 11 controlled trials $(n=9)$, quasi-experimental pre-test/posttest studies $(n=11)$, and one mixed-method study $(n=2)$. The characteristics of each study, quality of evaluation, and level of evidence were then assigned (Appendix 1). The studies were assessed for quality using the Critical Appraisal Skills Programme (CASP) [27] criteria selected by the relevancy to each study design: randomized controlled trial or experimental study. In Appendix 1, the results of the quality review are presented; and the key points of each study are summarized, including findings and the generalizability of the study. The level of evidence (LOE) was determined for each study using the Oxford Centre for Evidence-based Medicine Levels of Evidence Tool [28].

\section{Results}

Once the sample was collected and inclusion criteria were applied, the manuscripts were then evaluated based on the key concepts and demographics of included in each study.

\subsection{Population Characteristics}

To analyze the results, concepts and characteristics were tabulated using grouping and the displayed as the total number presenting with a certain characteristic. Characteristics of the sample populations are presented in Appendix 1. Compilation of the populations revealed that in a majority of the studies, the populations were primarily female $(n=21)$, white $(n=9)$ and well educated $(n=14)$. Seven of the 22 studies included participants from different countries or specific cultures [29]-[35] and four represented predominately African Americans [36][39]. Only six manuscripts $(n=6)$ focused specifically on older adults age 65 or older [30] [32] [36]-[38] [40]. The settings in which the studies took place varied. The majority of the studies used group-based activities in community or faith based centers; two used a home-based intervention [11] [40] and one a nursing home [32]. One large interventional study utilized multiple locations for self-management programs over 17 states [41]. Three of the studies in the integrative review recruited patients from the clinic setting [33] [42] [43].

The representation of chronic diseases in the studies included either a random mix or a disease specific focus with heart failure, diabetes, and arthritis being the predominate diagnoses (Appendix 1). Additionally, one study focused on self-management in lower back pain [44] while another focused on chronic pain management [45]. Of concern from the integrative review, the population characteristics for the studies conducted in the United States did not adequately represent participants from varying ethnicities or individuals with lower educational levels, both characteristics of social determinants of health are recognized as contributing to higher risk of mortality and death [46] [47].

\subsection{Theoretical Frameworks}

Nine studies did not identify a theoretical framework $(n=9)$ [11] [30] [32] [33] [38] [39] [44] [45] [48], while the concept of self-efficacy was used in several studies as the supporting structure for the research $(n=9)$. Three 
studies cited the use of the Social Learning Theory [31] [34] [35] and one used the Social Cognitive Theory [40] as support for the research framework.

\subsection{Outcome Measures}

Each study was evaluated for outcome measures related to the concepts of the Social Cognitive Theory, i.e. self-efficacy, observational learning, environmental determinants, self-regulation, and moral disengagement [8] summarized in Appendix 1. All studies evaluated the effects of self-efficacy in self-management programs. The methods for increasing self-efficacy included mastery experience, social role modeling, improving health status, and verbal persuasion [8]. Short-term effects were observed in most studies, whereas long-term retention of increased self-efficacy was rarely explored.

An increased emphasis on patient participation was found to improve outcomes [33]. Observational learning takes place through interactive learning and modeling of behaviors. Observational learning was identified through role modeling in a majority $(n=14)$ of the studies. Bandura linked role modeling to encouraging behavior change [24] [25]. Two studies focused either upon personal interactions in the home setting or did not use a group format [11] [40], one used individualized training in a nursing home [32]; the remaining studies used a variation of group observational learning.

Environmental determinants in the Social Cognitive Theory include barriers to self-management, planning, and ability to critically think of solutions when self-management behaviors are threatened [24]. Although most of the studies offered education concerning planning, goal setting, and preparedness, none of the studies evaluated barriers as potential inhibitors to self-management.

Self-regulation describes the ability of individuals to regulate behavior to manage the requirements of disease care. In the identified studies, self-regulation was consistently measured, but the specific indices varied. Most commonly, self-regulation was measured by the presence or absence of salient self-management behaviors, such as testing blood sugar, monitoring pain, or shortness of breath.

Although social support is an important component of self-monitoring success, the evaluation of social support systems as a variable of impact was not identified in these studies. A majority of the studies utilized a peer group setting as social support, but evaluation of social support quality or structure as a variable was not identified. Although self-management is an individual initiative, the adherence to self-management can be influenced by the presence and quality of social support systems. At the same time, studies did not focus predominantly on the older adult and the stage of life, which could conceivably provide a different view of social support. As aging occurs, there is also an increased incidence of co-morbidities which may alter the older adult's response to health behavior change [13]. Incorporating social support into the self-management program was not a measured variable in the studies.

Moral disengagement was the final category in evaluating the use of the Social Cognitive Theory in changing self-management behaviors. The evaluation of moral disengagement (beliefs) toward a disease was evaluated in only one study [35]. Assessing an individual's attitude toward both risky behavior and the process of behavior change is essential and could be crucial for future self-management success.

To determine the lasting effectiveness of the intervention on outcomes measures, studies were reviewed for post-intervention testing. The evaluation of the follow-up period after the intervention allowed for determination of knowledge of long-term effects of self-management. In this review, four of the studies $(n=4)$ had a single post-evaluation at six weeks which was directly after the intervention concluded. Five had an 8-week post intervention evaluation $(n=5)$ and 7 studies followed up at 6 months $(n=7)$. More long-term evaluations were seen at 12 months in 5 of the studies $(n=5)$ and one study with a two year follow-up period $(n=1)$ [49].

\section{Discussion}

A limited number of studies analyzed for this review focused exclusively on older adult populations. With epidemiological data confirming that worldwide older adult populations have poorer chronic disease outcomes than the general population, effective self-management methods are indicated. The burden of disease on the individual and the healthcare system suggests that global initiatives should continue to focus on self-management with an emphasis on finding creative and innovative methods to improve participation in this population. There was also a shortage of long-term evaluation of the impact of self-management of chronic disease. Due to the lack of both consistency in study parameters and longevity in studies, the findings are inconclusive as to whether self- 
management provides improved outcomes long-term. These findings are consistent with earlier reviews of selfmanagement [10] [50] [51]. These findings support a gap in literature regarding older adults (those 65 years and older) with chronic disease using self-management.

Additionally, the samples in the evaluated studies were predominately white, well educated, females and did not represent the population most at risk for complications. Although it is recognized that improving chronic disease management in all populations is essential, certain groups with chronic diseases have been identified as experiencing significant decreases in life expectancy. This finding suggests that the target population should include both those at higher risk for death from chronic diseases and those who have identified social determinants of health such as low educational level and income [46] [47]. Based on data compared in the integrative review, more research should be conducted with the growing sub-populations of minorities, those over the age of 65, and those with lower educational level and low incomes, and those living in rural areas with limited healthcare access.

Use of a theoretical framework and inclusion of all components of the theory into a study are not mandated but supports proposed research framework. The purpose of this review was not to evaluate the use of theory in totality, but to identify concepts related to SCT that have not been previously studied. The lack of long-term adherence to self-management programs highlights the need to include additional concepts into future research models.

In evaluating concept application, self-efficacy as well as self-regulation and observational learning were consistently measured in the studies. The finding was not unexpected. However, several key components were not examined in these studies. Social support (other than peer support although its impact was not measured), moral disengagement, and barriers to environmental determinants were not mentioned in the studies.

In the integrative review, analysis of the studies revealed that long-term effects of self-management behaviors have not been sufficiently researched. Although initial results immediately post-intervention showed positive significant results impacting self-management behaviors and quality of life, the specific outcome measures that were impacted varied. The analysis of long-term improvements revealed that the groups did not continue to increase or plateau but decreased over time.

\section{Conclusion and Implications}

This integrative review has raised several questions and identified significant gaps in the literature. Self-management, in short-term interventions, has shown to improve outcome measures. The extensive variation in the methods used to measure outcomes requires further validation in subsequent inquiries in order to draw conclusive results. In addition, future studies with larger sample sizes and population-specific participants should evaluate consistent implementation of self-management strategies. Also, focusing research on the at-risk population that would potentially benefit most from self-management interventions is a component that has not been sufficiently explored. Education, social support, gender, and race can be associated with the development of chronic disease and poor outcomes in these high risk populations [46] [52]. Few studies in the integrative review, however, focused on these specific issues as sample characteristics in the older adult population.

Although a majority of the studies used a group intervention in community centers, assessment of the social support network either available to or preferred by the older adult was not mentioned. As social support and the encompassing social determinants of health represent a significant characteristic of those most at risk for developing or having complications from chronic disease, investigation with attention to these characteristics is paramount in the global epidemic of chronic disease.

Another query raised is the use of moral disengagement. Although moral disengagement has been identified as a significant barrier to behavior change it was not addressed in the studies. Assessing individuals' attitudes toward their current behaviors and the significance that they put on a new behavior is extremely important in overcoming potential barriers to successful incorporation of behavior change. The investigation of the role of moral disengagement requires further study to determine the impact on behavior change in this population.

As the chronic disease epidemic impacts not only the U.S but also countries around the world, these findings are relevant to nurse researchers globally. Establishing self-management as an effective strategy is a timely and relevant topic for exploration. With the global focus of healthcare on the provision of chronic disease management, replication of previous smaller studies to validate findings in diverse populations would be beneficial. These studies would also ensure that self-management programs include holistic approaches to behavior change 
in chronic disease. The results of this integrative review has demonstrated several gaps in the literature regarding use of social support in self-management, impact of moral disengagement, and studies specifically targeting older adults. In addition, future interventional research should focus on developing effective long-term strategies for self-management success in older adults.

\section{References}

[1] World Health Organization (2005) 10 Facts about Chronic Disease. http://www.who.int/features/factfiles/chp/01_en.html

[2] WHO (2011) Noncommunicable Disease Country Profiles 2011.

[3] Centers for Disease Control and Prevention (2013) The State of Aging \& Health in America 2013. Centers for Disease Control and Prevention, US Department of Health and Human Services, Atlanta.

[4] World Health Organization (2012) Assessing National Capacity for Prevention and Controlling Noncommunicable Diseases.

[5] Whittemore, R. and Dixon, J. (2008) Chronic Illness: The Process of Integration. Journal of Clinical Nursing, 17, 177187. http://dx.doi.org/10.1111/j.1365-2702.2007.02244.x

[6] Lorig, K. and Holman, H.R. (2003) Self-Management Education: History, Definition, Outcomes, and Mechanisms. Annals of Behavioral Medicine, 26, 1-7. http://dx.doi.org/10.1207/S15324796ABM2601_01

[7] Walker, C., Swerissen, H. and Belfrage, J. (2003) Self-Management: Its Place in the Management of Chronic Illness. Australian Health Review, 26, 34-42. http://dx.doi.org/10.1071/AH030034a

[8] Glanz, K., Rimer, B.K. and Viswanath, K., Eds. (2008) Health Behavior and Education. 4th Edition, San Francisco, Jossey-Bass.

[9] Bandura, A. (2004) Health Promotion by Social Cogntive Means. Health Education \& Behavior, 31, 143-164. http://dx.doi.org/10.1177/1090198104263660

[10] Chodosh, J., et al. (2005) Chronic Disease Self-Management for Older Adults. Annals of Internal Medicine, 143, 427438. http://dx.doi.org/10.7326/0003-4819-143-6-200509200-00007

[11] Jerant, A., Moore-Hill, M. and Franks, P. (2009) Home-Based, Peer-Led Chronic Illness Self-Management Training: Findings from a 1-Year Randomized Controlled Trial. Annals of Family Medicine, 7, 319-327. http://dx.doi.org/10.1370/afm.996

[12] World Health Organization (2013) Health Topics Chronic Disease. http://www.who.int/topics/chronic_diseases/en/

[13] Clark, N.M., Becker, M.H., Janz, N.K., Lorig, K., Rakowski, W. and Anderson, L. (1991) Self-Management of Chronic Disease by Older Adults. Journal of Aging and Health, 3, 4-27. http://dx.doi.org/10.1177/089826439100300101

[14] Administration on Aging (2011) Aging in the 21st Century. D.o.H.a.H. Services.

[15] WHO (2012) Disability and Health Fact Sheet.

[16] Centers for Medicare and Medicaid Services (2010) National Expenditure Projections 2010-2020: Forecast Summary.

[17] Di lorio, C.K. (2005) Measurement in Health Behavior. Jossey-Bass, San Francisco.

[18] US Department of Health and Human Resources (2012) Healthy People 2020.

[19] WHO (2011) Global Health and Aging.

[20] GOLD Executive Committee (2006) Global Initiative for Chronic Obstructive Lung Disease, in National Heart, Lung and Blood Institute/World Health Organization Workshop.

[21] GOLD Executive Committee (2008) Global Strategy for the Diagnosis, Management, and Prevention of Chronic Obstructive Pulmonary Disease.

[22] Udlis, K. (2011) Self-Management in Chronic Illness: Concept and Dimensional Analysis. Journal of Nursing and Healthcare of Chronic Illness, 3, 130-139. http://dx.doi.org/10.1111/j.1752-9824.2011.01085.x

[23] Kawi, J. (2012) Self-Management Support in Chronic Illness Care: A Concept Analysis. Research \& Theory for Nursing Practice, 26, 108-125. http://dx.doi.org/10.1891/1541-6577.26.2.108

[24] Bandura, A. (1986) Social Foundation of Thoughts and Action: A Social Cognitive Theory. Prentice-Hall, Inc., Upper Saddle River.

[25] Bandura, A. (1997) Self-Efficacy: The Exercise of Control. W.H. Freeman and Company, New York.

[26] Conn, V.S., Valentine, J.C. and Cooper, H.M. (2003) Grey Literature in Meta-Analyses. Nursing Research, 52, 256261. http://dx.doi.org/10.1097/00006199-200307000-00008

[27] Solutions for Public Health (2013) Critical Appraisal Skills Programme. 
[28] Centre for Evidenced Based Medicine (2009) Study Designs.

[29] Tomioka, M., Braun, K.L., Compton, M. and Tanoue, L. (2011) Adapting Stanford's Chronic Disease Self-Management Program to Hawaii’s Multicultural Population. The Gerontologist, 52, 121-132. http://dx.doi.org/10.1093/geront/gnr054

[30] Chan, W.L.S., Hui, E., Chan, C., Cheung, D., Wong, S., Wong, R., Li, S. and Woo, J. (2011) Evaluation of Chronic Disease Self-Management Programme (CDSMP) for Older Adults in Hong Kong. The Journal of Nutrition, Health, \& Aging, 15, 209-214. http://dx.doi.org/10.1007/s12603-010-0257-9

[31] Kao, K.J., Wu, M.-P., Tsai, M.-W., Chang, W.-W. and Wu, S.-F. (2012) The Effectiveness of a Self-Management Program on Quality of Life for Knee Osteoarthritis. Archives of Gerontology and Geriatrics, 54, 317-324. http://dx.doi.org/10.1016/j.archger.2011.05.018

[32] Park, Y.H., Chang, H.K., Kim, J.S. and Kwak, J.S. (2012) Patient-Tailored Self-Management Intervention for Older Adults with Hypertension in a Nursing Home. Journal of Clinical Nursing, 27, 710-711. http://dx.doi.org/10.1111/j.1365-2702.2012.04236.x

[33] Harvey, P.W., Petkov, J.N., Misan, G., Fuller, J., Battersby, M.W., Cayetano, T.N., Warren, K. and Holmes, P. (2008) Self-Management Support and Training for Patients with Chronic and Complex Conditions Improves Health-Related Behavior and Outcomes. Australian Health Review, 32, 330-338. http://dx.doi.org/10.1071/AH080330

[34] Swerrisen, H., Belfrage, J., Weeks, A., Jordan, L., Walker, C., Furler, J., McAvoy, B., Carter, M. and Peterson, C. (2006) A Randomised Control Trial of a Self-Management Program for People with a Chronic Illness from Vietnamese, Chinese, Italian, and Greek Backgrounds. Patient Education and Counseling, 64, 360-368. http://dx.doi.org/10.1016/j.pec.2006.04.003

[35] Wu, S.V., Kao, M.-J., Wu, M.-P., Tsai, M.-W. and Chang, W.-W. (2011) Effects of an Osteoarthritis Self-Management Programme. Journal of Advanced Nursing, 67, 1491-1501. http://dx.doi.org/10.1111/j.1365-2648.2010.05603.x

[36] Gitlin, L.N., Chernett, N.L., Harris, L.F., Palmer, D., Hopkins, P. and Dennis, M.P. (2008) Harvest Health: Translation of the Chronic Disease Self-Management Program for Older African Americans in a Senior Setting. The Gerontologist, 48, 698-705. http://dx.doi.org/10.1093/geront/48.5.698

[37] Rose, M., Arenson, C., Harrod, P., Salkey, R., Santana, A. and Diamond, J. (2009) Evaluation of the Chronic SelfManagement Program with Low-Income Urban, African American Older Adults. Journal of Community Health Nursing, 25, 193-202. http://dx.doi.org/10.1080/07370010802421178

[38] Speer, E.M., et al. (2008) Diabetes Self-Management Behaviors and A1c Improved Following a Community-Based Intervention in Older Adults in Georgia Senior Centers. Journal of Nutrition for the Elderly, 27, 179-200. http://dx.doi.org/10.1080/01639360802060298

[39] Goeppinger, J., Armstrong, B., Schwartz, T., D.E. and Brady, T.J. (2007) Self-Management Education for Persons with Arthritis: Managing the Comorbidity and Eliminating Health Disparities. Arthritis and Rheumatism, 57, 1081-1087. http://dx.doi.org/10.1002/art.22896

[40] Laforest, S., Nour, K., Gignac, M., Gauvin, L., Parisien, M. and Poirier, M.-C. (2008) Short-Term Effects of a Self-Management Intervention on Health Status of Housebound Older Adults with Arthritis. Journal of Applied Gerontology, 27, 539-567. http://dx.doi.org/10.1177/0733464808319712

[41] Ory, M.G., et al. (2013) National Study of Chronic Disease Self-Management: Six-Month Outcome Findings. Journal of Aging and Health, 25, 1258-1274. http://dx.doi.org/10.1177/0898264313502531

[42] Smeulders, E.S., et al. (2010) Nurse-Led Self-Management Group Programme for Patient with Congestive Heart Failure: Randomized Controlled Trial. Journal of Advanced Nursing, 66, 1487-1499. http://dx.doi.org/10.1111/j.1365-2648.2010.05318.x

[43] Farrell, K., Wicks, M.N. and Martin, J.C. (2004) Chronic Disease Self-Management Improved with Enhanced Self-Efficacy. Clinical Nursing Research, 13, 289-308. http://dx.doi.org/10.1177/1054773804267878

[44] Haas, M., et al. (2005) Chronic Disease Self-Management Program for Low Back Pain in Elderly. Journal of Manipulative and Physiological Therapeutics, 28, 228-237. http://dx.doi.org/10.1016/j.jmpt.2005.03.010

[45] Ersek, M., Turner, J.A., Cain, K.C. and Kemp, C.A. (2008) Results of a Randomized Controlled Trial to Examine the Efficacy of a Chronic Pain Self-Management Program for Older Adults. Pain, 138, 29-40. http://dx.doi.org/10.1016/j.pain.2007.11.003

[46] Marmot, M. and Wilkinson, R.G., Eds. (2006) Social Determinants of Health. 2nd Edition, Oxford University Press, Oxford.

[47] World Health Organization (2013) Social Determinants of Health Key Concepts.

[48] Klug, C., Toobert, D.J. and Fogerty, M. (2008) Healthy Changes for Living with Diabetes: An Evidenced-Based Community Diabetes Self-Management. The Diabetes Educator, 34, 1053-1061. http://dx.doi.org/10.1177/0145721708325886 
[49] Lorig, K., et al. (2001) Chronic Disease Self-Management Program: 2-Year Health Status and Health Care Utilization Outcomes. Medical Care, 39, 1217-1223. http://dx.doi.org/10.1097/00005650-200111000-00008

[50] Coster, S. and Norman, I. (2009) Cochrane Reviews of Educational and Self-Management Interventions to Guide Nursing Practice: A Review. International Journal of Nursing Studies, 46, 508-528.

http://dx.doi.org/10.1016/j.ijnurstu.2008.09.009

[51] Radhakrishnan, K. (2011) The Efficacy of Tailored Interventions for Self-Management Outcomes of Type 2 Diabetes, Hypertension or Heart Disease: A Systematic Review. Journal of Advanced Nursing, 68, 496-510. http://dx.doi.org/10.1111/j.1365-2648.2011.05860.x

[52] World Health Organization (2013) Health Topics: Chronic Disease. 
Appendix 1. Self-Management in Older Adults with Chronic Disease

\begin{tabular}{|c|c|c|c|c|c|c|c|c|c|}
\hline Citation & Purpose & $\begin{array}{l}\text { Theoretical } \\
\text { Framework }\end{array}$ & Setting & Design & Sample & $\begin{array}{l}\text { Outcomes } \\
\text { Measurement }\end{array}$ & Results/Findings & $\begin{array}{c}\text { Author } \\
\text { Interpretation/ } \\
\text { Limitations }\end{array}$ & LOE \\
\hline $\begin{array}{l}\text { Ory, M., } \\
\text { et al. } \\
\text { (2013) }\end{array}$ & $\begin{array}{l}\text { Purpose: } \\
\text { Evaluate the } \\
\text { effect of the } \\
\text { CDSMP on } \\
\text { health } \\
\text { outcomes, } \\
\text { lifestyle } \\
\text { behaviors, } \\
\text { and } \\
\text { healthcare } \\
\text { utilization }\end{array}$ & Self-efficacy & $\begin{array}{c}\text { Multiple } \\
\text { community } \\
\text { sites in } 17 \\
\text { states. } \\
\text { U.S. }\end{array}$ & $\begin{array}{l}\text { - Pre-post Design } \\
\text { Role modeling } \\
\text { with peer } \\
\text { led groups. } \\
\text { - 6-month } \\
\text { follow-up. }\end{array}$ & $\begin{array}{l}\text { - } \mathrm{N}=1170 \\
\text { - } \text { Mean age } 65 \\
\text { - Female = } 83 \% \\
\text { - } \text { White = } 55 \% \\
\text { - Education } \\
\text { Mean } 12 \text { years } \\
\text { - Heterogeneous } \\
\text { Disease } \\
\text { Sample }\end{array}$ & $\begin{array}{l}\text { - Social/Role } \\
\text { Limitations } \\
\text { - Depression } \\
\text { - Communication } \\
\text { with physicians } \\
\text { - Health related } \\
\text { behaviors }\end{array}$ & $\begin{array}{l}\text { Findings: } \\
\text { Significant } \\
\text { improvement } \\
\text { in outcomes } \\
\text { at } 6 \text { months }\end{array}$ & $\begin{array}{l}\text { Conclusions: } \\
\text { - Confirms improved } \\
\text { outcomes in older adults } \\
\text { - Improved quality of life } \\
\quad \text { Limitations: } \\
\text { - No control group } \\
\text { - Greater variability } \\
\text { in community } \\
\text { based programs } \\
\text { - Self-report of variables }\end{array}$ & $2 \mathrm{~b}$ \\
\hline $\begin{array}{l}\text { Park, } \\
\text { Y.H. } \\
\text { et al. } \\
\text { (2012) }\end{array}$ & $\begin{array}{l}\text { Purpose: Evaluate } \\
\text { the effects of an } \\
\text { individualized } \\
\text { self-management } \\
\text { intervention } \\
\text { for nursing home } \\
\text { patients with } \\
\text { hypertension }\end{array}$ & None & $\begin{array}{l}\text { Nursing } \\
\text { Home } \\
\text { Korea }\end{array}$ & $\begin{array}{l}\text { - Non-equivalent } \\
\text { comparison group } \\
\text { - } 8 \text { week post } \\
\text { intervention } \\
\text { evaluation } \\
\text { - Provider } \\
\text { Led education }\end{array}$ & 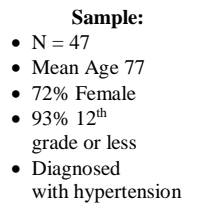 & $\begin{array}{l}\text { - Blood Pressure and } \\
\text { self-care behaviors }\end{array}$ & $\begin{array}{c}\text { Findings: } \\
\text { Intervention group } \\
\text { was found to have } \\
\text { lower blood pressure } \\
\text { and increased activity. } \\
\text { No difference in } \\
\text { medication adherence. }\end{array}$ & $\begin{array}{l}\text { Conclusions: } \\
\text { Effective intervention, } \\
\text { but need further } \\
\text { studies to validate. } \\
\text { Limitations: } \\
\text { - Small sample size, } \\
\text { - Convenience sample }\end{array}$ & $2 \mathrm{~b}$ \\
\hline $\begin{array}{l}\text { Chan } \\
\text { et al. } \\
\text { (2011) }\end{array}$ & $\begin{array}{l}\text { Evaluate the } \\
\text { effectiveness } \\
\text { of the Chronic } \\
\text { Disease } \\
\text { Self-Management } \\
\text { Program } \\
\text { (CDSMP) } \\
\text { adapted in } \\
\text { Hong Kong }\end{array}$ & $\begin{array}{l}\text { None } \\
\text { stated }\end{array}$ & $\begin{array}{l}\text { Community } \\
\text { based } \\
\text { organizations } \\
\text { samples in } \\
\text { groups per } \\
\text { locality } \\
\text { Hong Kong }\end{array}$ & $\begin{array}{l}\text { - Longitudinal, } \\
\text { Quasi-experimental } \\
\text { - } 6 \text { weekly sessions } \\
\text { - } 6 \text { month follow-up } \\
\text { - Adapted program } \\
\text { by trained } \\
\text { professional } \\
\text { or lay leader } \\
\text { - } 6 \text { month follow-up }\end{array}$ & $\begin{array}{l}\text { - } \mathrm{N}=302 \\
\text { Intervention } \\
\text { - } \mathrm{N}=298 \text { control } \\
\text { - Mean Age: } \\
\text { - Intervention: } \\
73 \text { years } 77 \% \text { female } \\
\text { - Control: } \\
76 \text { years } 83 \% \text { Female } \\
\text { - Education: } 4 \text { years } \\
\text { both groups } \\
\text { - Heterogeneous } \\
\text { Disease } \\
\text { population }\end{array}$ & $\begin{array}{l}\text { - Demographics; } \\
\text { self-management } \\
\text { behaviors; } \\
\text { self-efficacy; health } \\
\text { status; healthcare } \\
\text { utilization } \\
\text { (validity and } \\
\text { reliability not } \\
\text { stated) } \\
\end{array}$ & $\begin{array}{l}\text { - Interventional group } \\
\text { showed significant } \\
\text { increase in } \\
\text { self-efficacy } \\
(p<0.005) \text { with } \\
\text { control group } \\
\text { deteriorating } \\
\text { from baseline } \\
\text { - Health Status: } \\
\text { - activity limitations } \\
\text { decreased ( } p<0.004) \\
\text { - depressive symptoms } \\
\text { ( } p<0.001) \\
\text { - health distress } \\
\text { decrease }(p<0.014) \\
\text { - Pain and discomfort } \\
\text { decrease }(p=0.006) \\
\text { - -No difference in } \\
\text { healthcare utilization }\end{array}$ & $\begin{array}{l}\text { Interpretation: } \\
\text { - At } 6 \text { months there were } \\
\text { improvements in } \\
\text { self-management } \\
\text { behaviors, self-efficacy, } \\
\text { and health outcomes in } \\
\text { treatment group. } \\
\text { Reported Limitations: } \\
\text { - Random sampling not } \\
\text { utilized, volunteers } \\
\text { might have improved } \\
\text { motivation to participate, } \\
\text { need longer follow-up, } \\
\text { baseline data adjusted } \\
\text { for group differences } \\
\text { could affect ability to } \\
\text { detect changes } \\
\text { Generalizability: } \\
\text { to locality, } \\
\text { volunteers } \\
\text { could limit } \\
\text { generalizability }\end{array}$ & $2 \mathrm{~b}$ \\
\hline $\begin{array}{l}\text { Kao et al. } \\
\text { (2011) }\end{array}$ & $\begin{array}{c}\text { Evaluate } \\
\text { effectiveness of } \\
\text { self-management } \\
\text { program in } \\
\text { patients with knee } \\
\text { osteoarthritis } \\
\text { (TOAP program) }\end{array}$ & $\begin{array}{l}\text { Self-Efficacy } \\
\text { Theory and } \\
\text { Social } \\
\text { Learning } \\
\text { Theory }\end{array}$ & $\begin{array}{c}\text { Taiwan: } \\
4 \text { districts in } \\
\text { Taipei } \\
2 \text { districts } \\
\text { assigned to } \\
\text { intervention } \\
\text { and then } \\
\text { divided into } \\
\text { smaller groups } \\
\text { for program } \\
\text { delivery } \\
2 \text { districts } \\
\text { assigned to } \\
\text { control }\end{array}$ & $\begin{array}{l}\text { - Quasi-experimental } \\
\text { - Routine Care versus } \\
\text { TOAP intervention } \\
\text { - Measurement } \\
\text { baseline, } \\
\text { immediately } \\
\text { post-intervention, } \\
\text { and } 8 \text { weeks }\end{array}$ & $\begin{array}{l}\text { - } \mathrm{N}=205 \\
\text { - } \mathrm{CG}=91 \\
\text { - } \mathrm{IG}=114 \\
\text { - } \mathrm{Mean} \text { Age = } 67 \\
\text { - } 80.7 \% \text { Female } \\
\text { - } 47 \% \text { with } \\
\text { elementary or } \\
\text { less education } \\
\text { - } 30 \% \text { High School } \\
\text { Education } \\
\text { - Diagnosed } \\
\text { with arthritis }\end{array}$ & $\begin{array}{l}\text { - Demographics; } \\
\text { Health Related } \\
\text { Quality of Life } \\
\text { (SF-36); } \\
\text { Disability- } \\
\text { TWOMAC- } \\
\text { reliability and } \\
\text { validity of } \\
\text { both previously } \\
\text { established }\end{array}$ & $\begin{array}{l}\text { - No statistical } \\
\text { difference in } \\
\text { disability measures } \\
\text { from baseline to } 8 \\
\text { weeks. } \\
\text { - SF-36 subscale in } \\
\text { general health and } \\
\text { emotional status } \\
\text { showed } \\
\text { improvement in } \\
\text { control group } \\
\text { but was not } \\
\text { statistically } \\
\text { significant }\end{array}$ & $\begin{array}{l}\text { Interpretation: } \\
\text { - The increase in mental } \\
\text { scores (MCS) on the } \\
\text { SF-36 could indicate } \\
\text { increased psychology } \\
\text { benefits as lower MCS } \\
\text { has been linked to } \\
\text { depression, } \\
\text { unhappiness, etc. } \\
\text { that has been } \\
\text { demonstrated in } \\
\text { other studies. } \\
\text { - Physical benefits are } \\
\text { linked to increased } \\
\text { exercise protocols. } \\
\text { - There was not a } \\
\text { significant change in the } \\
\text { IG in disability or pain } \\
\text { supporting that } \\
\text { self-management } \\
\text { provides } \\
\text { psychology benefits. } \\
\text { Limitations: } \\
\text { - Cluster randomization } \\
\text { could decrease } \\
\text { participation and limit } \\
\text { data to the immediate } \\
\text { population. } \\
\text { - Self-report instruments } \\
\text { creating possible response } \\
\text { bias. } \\
\text { Generalizability: } \\
\text { Cannot be generalized } \\
\text { due to lower } \\
\text { education percentage, } \\
\text { volunteers could limit } \\
\text { generalizability }\end{array}$ & $2 \mathrm{~b}$ \\
\hline
\end{tabular}




\section{Continued}

\begin{tabular}{|c|c|c|c|c|c|c|c|c|c|}
\hline $\begin{array}{l}\text { Tomioka } \\
\text { et al. } \\
\text { (2011) }\end{array}$ & $\begin{array}{l}\text { Replication of } \\
\text { the CDSMP } \\
\text { in Asian and } \\
\text { Pacific Islanders }\end{array}$ & $\begin{array}{l}\text { Self-Efficacy } \\
\text { Theory }\end{array}$ & $\begin{array}{c}\text { Community } \\
\text { based } \\
\text { Area Agency } \\
\text { on Aging } \\
\text { employees } \\
\text { as leaders } \\
\text { Asian/Pacific } \\
\text { Islanders, U.S. }\end{array}$ & $\begin{array}{l}\text { - Pretest and posttest } \\
\text { design } \\
\text { - } 6 \text { week workshop } \\
\text { with } 6 \text { month } \\
\text { follow-up }\end{array}$ & $\begin{array}{l}\text { - } \mathrm{N}=675 \\
\text { - Mean age: } 72 \\
\text { - Caucasians: } 18 \% \\
\text { - Asians: } 40.4 \% \\
\text { - Native Hawaiian } \\
\text { Pacific Islanders: } \\
42 \% \\
\text { - } 86 \% \text { female } \\
\text { - } 36 \% \text { with at } \\
\text { least a high school } \\
\text { education } \\
\text { - Heterogeneous } \\
\text { Disease Sample }\end{array}$ & $\begin{array}{l}\text { - Demographics, } \\
\text { Health outcomes } \\
\text { Survey assesses } \\
\text { health status, } \\
\text { health behaviors, } \\
\text { self-efficacy, } \\
\text { communication } \\
\text { with providers } \\
\text { (HCP), and } \\
\text { healthcare } \\
\text { utilization } \\
\text { Validity and } \\
\text { Reliability not } \\
\text { addressed. } \\
\text { Program adapted } \\
\text { from CDSMP } \\
\text { which has } \\
\text { published } \\
\text { validity and } \\
\text { reliability of } \\
\text { outcome } \\
\text { measures } \\
\end{array}$ & $\begin{array}{l}\text { Health Status: } \\
\text { - Significant results } \\
\text { for self-rated } \\
\text { health in Asian } \\
\text { and NHPIs } \\
\text { ( } p=0.001) \\
\text { Health distress } \\
\text { improvements } \\
\text { significant for } \\
\text { Caucasians } \\
\text { (0.005) and } \\
\text { Asians (0.001) } \\
\text { Self-Efficacy: } \\
\text { - Self-efficacy } \\
\text { significant in } \\
\text { Asians (0.001) } \\
\text { and Caucasians } \\
\text { (0.012) } \\
\text { - Communication } \\
\text { with HCP all } \\
\text { groups } \\
\text { statistically } \\
\text { significant } \\
\text { Health Behaviors: } \\
\text { - Exercise and } \\
\text { stretching Asian } \\
\text { sample statistically } \\
(0.001) \text { and (0.001) } \\
\text { respectively } \\
\text { Health Care } \\
\text { Utilization: } \\
\text { - Asians } \\
\text { statistically } \\
\text { significant ( } 0.001)\end{array}$ & $\begin{array}{l}\text { Interpretation: } \\
\text { Higher completion } \\
\text { rates than previous } \\
\text { studies. AT } 6 \text { months } \\
\text { Asian participants } \\
\text { continued to } \\
\text { show benefits. } \\
\text { Limitations: } \\
\text { AoA employees as } \\
\text { leaders had difficulty } \\
\text { finding time to teach. } \\
\text { Loss of leaders to job } \\
\text { changes and moves. } \\
\text { Self-reported data, } \\
\text { inconsistent program } \\
\text { evaluation between sites. } \\
\text { Generalizability: } \\
\text { To API communities, } \\
\text { volunteers could limit } \\
\text { generalizability }\end{array}$ & $2 b$ \\
\hline $\begin{array}{l}\text { Wu et al. } \\
\text { (2011) }\end{array}$ & $\begin{array}{c}\text { Assess } \\
\text { effectiveness of } \\
\text { self-management } \\
\text { program in } \\
\text { osteoarthritis } \\
\text { patients }\end{array}$ & $\begin{array}{l}\text { Social } \\
\text { Learning } \\
\text { Theory }\end{array}$ & $\begin{array}{l}\text { Community } \\
\text { Residing } \\
\text { Hong Kong }\end{array}$ & $\begin{array}{l}\text { - Quasi-experimental } \\
\text { design } \\
\text { - } 4 \text { weekly classes, } \\
\text { post-test with } \\
\text { - } 8 \text { week follow-up } \\
\text { - Class size } 10-15\end{array}$ & $\begin{array}{l}\text { - Taiwanese sample, } \\
\text { assigned by districts } \\
\text { - } \mathrm{N}=215 \\
\text { - } \text { Control = } 125 \\
\text { - Intervention = } 134 \\
\text { - } \text { Mean Age: } 67 \\
\text { - } 70 \% \text { Female } \\
\text { - } 24 \% \text { College } \\
\text { graduate } \\
\text { - } 43 \% \text { had education } \\
\text { levels elementary or } \\
\text { below } \\
\text { Diagnosed with } \\
\text { Osteoarthritis }\end{array}$ & $\begin{array}{l}\text { - Demographics at } \\
\text { baseline } \\
\text { - Self-efficacy: } \\
\text { - Arthritis Self } \\
\text { Efficacy (ASE) } \\
\text { and ASE other } \\
\text { outcomes } \\
\text { (previously shown } \\
\text { valid and reliable) } \\
\text { - Change in Pain } \\
\text { Beliefs } \\
\text { - Health Care } \\
\text { Utilization } \\
\text { Panel of experts } \\
\text { determined } \\
\text { content validity; } \\
\text { test-retest } \\
\text { reliability } \\
\text { coefficient }\end{array}$ & $\begin{array}{l}\text { - Baseline showed no } \\
\text { statistical difference } \\
\text { - Intervention Group: } \\
\text { Statistically } \\
\text { significant of ASE } \\
\text { and ASE-OS at } \\
\text { follow-up }(P<0.001) \\
\text { - Changes in pain } \\
\text { beliefs in } \\
\text { interventional group } \\
\text { statistically } \\
\text { significant at each } \\
\text { measurement } \\
(P<0.001) \\
\text { - Decrease in medical } \\
\text { consultations } \\
\text { significantly } \\
\text { decreased in } \\
\text { intervention group } \\
(P<0.003)\end{array}$ & $\begin{array}{l}\text { Interpretation: } \\
\text { Greater increase in } \\
\text { self-efficacy suggests } \\
\text { that learning } \\
\text { self-efficacy behaviors } \\
\text { increase self-efficacy, } \\
\text { but over time fostering } \\
\text { these behaviors results } \\
\text { in a larger increase. } \\
\text { Limitations: } \\
\text { Self-report, lack of } \\
\text { blindness of participants, } \\
\text { (locality assignments } \\
\text { used to decreased } \\
\text { contamination), } \\
\text { low follow-up rate, } \\
8 \text { weeks not long } \\
\text { enough to determine } \\
\text { long-term effects } \\
\text { Generalizability: } \\
\text { Small sample size } \\
\text { cannot be generalized; } \\
\text { district location, } \\
\text { volunteers could } \\
\text { limit generalizability }\end{array}$ & $2 b$ \\
\hline $\begin{array}{l}\text { Smeulders } \\
\text { et al. } \\
\text { (2010) }\end{array}$ & $\begin{array}{l}\text { Evaluate the } \\
\text { effectiveness } \\
\text { of a nurse lead } \\
\text { self-management } \\
\text { group in patients } \\
\text { with heart failure }\end{array}$ & $\begin{array}{l}\text { Self-Efficacy } \\
\text { Theory }\end{array}$ & $\begin{array}{l}\text { Cardiac and } \\
\text { Heart } \\
\text { Failure Clinics } \\
\text { Netherlands }\end{array}$ & $\begin{array}{l}\text { - RCT with 12-month } \\
\text { follow-up } \\
\text { - } 6 \text { weekly sessions } \\
\text { - Leaders nurses } \\
\text { with two lay role } \\
\text { models } \\
\text { participating }\end{array}$ & $\begin{array}{l} \\
\\
\text { - } \mathrm{N}=317 \\
\text { - } \mathrm{IG}=186(76 \% \\
\text { male) } \\
\text { - } \mathrm{CG}=131 \\
\text { ( } 67 \% \text { male) } \\
\text { - Educational level: } \\
\text { - CG: } 69 \% \\
\text { Secondary } \\
\text { educations } \\
\text { - IG: } 64 \% \\
\text { - Diagnosed } \\
\text { with heart failure } \\
\end{array}$ & $\begin{array}{l}\text { - Demographics } \\
\text { - Self-Care: } \\
\text { European Heart } \\
\text { Failure Self-Care } \\
\text { Behavior Scale } \\
\text { - QOL: RAND } 36 \\
\text { item general } \\
\text { health; Kansas City } \\
\text { Cardiomyopathy } \\
\text { Questionnaire } \\
\text { - Psychosocial } \\
\text { attributes: } \\
\text { Perceived } \\
\text { Autonomy by } \\
\text { Visual Analog } \\
\text { Scale } \\
\text { - Anxiety and } \\
\text { Depression: } \\
\text { Hospital Anxiety } \\
\text { and Depression } \\
\text { Scale } \\
\text { Stated that } \\
\text { instruments were } \\
\text { valid and reliable. }\end{array}$ & $\begin{array}{l}\text { - In comparison } \\
\text { of groups: } \\
\text { - Perceived control } \\
\text { and self-efficacy } \\
\text { did not show } \\
\text { significant change. } \\
\text { - After intervention } \\
\text { IG: Cognitive } \\
\text { Symptoms } \\
\text { management } \\
(P=0.001), \\
\text { self-care }(P=0.008) \text {, } \\
\text { QOL (0.005) } \\
\text { - No statistical } \\
\text { different at } \\
6 \text { and } 12 \text { months. }\end{array}$ & $\begin{array}{l}\text { Interpretations: } \\
\text { Statistically significant } \\
\text { results suggest that further, } \\
\text { long term studies should } \\
\text { be undertaken in the } \\
\text { patients with } \\
\text { heart failure } \\
\text { Limitations: } \\
\text { only study } \\
\text { with heart failure } \\
\text { patients; } \\
\text { Not able to enroll } \\
\text { enough for power } \\
\text { to be achieved; } \\
\text { Self-report } \\
\text { instruments; } \\
\text { low follow-up } \\
\text { Generalizability } \\
\text { Cannot be generalized } \\
\text { due to limitations, } \\
\text { volunteers could } \\
\text { limit generalizability }\end{array}$ & $1 \mathrm{~b}$ \\
\hline
\end{tabular}




\section{Continued}

\begin{tabular}{|c|c|c|c|c|c|c|c|c|c|}
\hline $\begin{array}{l}\text { Jerant } \\
\text { et al. } \\
(2009)\end{array}$ & $\begin{array}{l}\text { Assess long-term } \\
\text { effects of the } \\
\text { CDSMP } \\
\text { beyond } \\
6 \text { months }\end{array}$ & Not stated & $\begin{array}{l}\text { Home based } \\
\text { variant of } \\
\text { CDSMP called } \\
\text { Homing in } \\
\text { on Health } \\
\text { (HIOH) } \\
\text { U.S. }\end{array}$ & $\begin{array}{l}\text { RCT, measured at } \\
\text { baseline, } 6 \text { weeks, } 6 \\
\text { months, and } 1 \text { year. }\end{array}$ & $\begin{array}{l}\text { - } \mathrm{N}=415 \\
\text { - Convenience } \\
\text { sample } \\
\text { - Randomized to } \\
\text { usual care, HIOH, } \\
\text { or telephone } \\
\text { intervention. } \\
\text { - } 78 \% \text { - } 75 \% \\
\text { female per group } \\
\text { - Mean age: } 60 \\
\text { - Caucasian } 75 \% \\
\text { - Education: } \\
\text { majority some } \\
\text { college or beyond } \\
\text { - Heterogeneous } \\
\text { Disease Sample } \\
\end{array}$ & $\begin{array}{l}\text { - Demographics } \\
\text { - Self-Efficacy } \\
\text { (Cronbach's } \\
\text { alpha = 0.96) } \\
\text { - Health Status: } \\
\text { SF-36 } \\
\text { (previous } \\
\text { validation) } \\
\text { - Medical } \\
\text { Outcomes Survey } \\
\text { on General Health } \\
\text { and EuroQol (EQ) } \\
\text { health status and } \\
\text { Visual Analog } \\
\text { Scale (EQ VAS) } \\
\text { (validity not } \\
\text { addressed) } \\
\text { - Functional Ability: } \\
\text { Health-Assessment } \\
\text { Questionnaire } \\
\text { (composite } \\
\text { alpha 0.92) } \\
\text { - Hospital } \\
\text { days prior to study }\end{array}$ & $\begin{array}{l}\text { - The home group had } \\
\text { significant increase in } \\
\text { self-efficacy at } 6 \\
\text { weeks and } 6 \text { years, } \\
\text { but no difference at } 1 \\
\text { year. } \\
\text { - Health Status: the } \\
\text { EQ VAS was } \\
\text { increased in the } \\
\text { home group at all } \\
\text { three measured } \\
\text { intervals, all other } \\
\text { assessment of } \\
\text { health status } \\
\text { were not significant. } \\
\text { - There were no } \\
\text { significant effects } \\
\text { on hospitalization } \\
\text { at } 1 \text { year } \\
\text { - Statistical } \\
\text { significance } \\
\text { not addressed }\end{array}$ & $\begin{array}{l}\text { Interpretation: } \\
\text { Consistent with } \\
\text { previous studies that } \\
\text { suggest that the CDSMP } \\
\text { has short-term moderate } \\
\text { effects. Questions whether } \\
\text { implementation of CDSMP } \\
\text { would be cost effective. } \\
\text { Limitations: } \\
\text { Majority were Caucasian, } \\
\text { female, married, and } \\
\text { well-educated which } \\
\text { questions the } \\
\text { generalizability. } \\
\text { Participation was } \\
\text { voluntary which may } \\
\text { have affected the type } \\
\text { of population and the } \\
\text { dropout rate in the } \\
\text { intervention group } \\
\text { was high. Self-report } \\
\text { instruments } \\
\text { Generalizability: } \\
\text { limited due to sample } \\
\text { characteristics nor } \\
\text { representative of } \\
\text { population, volunteers } \\
\text { could limit } \\
\text { generalizability }\end{array}$ & $1 b$ \\
\hline $\begin{array}{l}\text { Rose } \\
\text { et al. } \\
\text { (2009) }\end{array}$ & $\begin{array}{c}\text { Evaluate the } \\
\text { effectiveness } \\
\text { of the CDSMP } \\
\text { when used with } \\
\text { Urban African } \\
\text { American older } \\
\text { adults }\end{array}$ & $\begin{array}{l}\text { Concept of } \\
\text { Self-efficacy }\end{array}$ & $\begin{array}{c}\text { Senior } \\
\text { center, } \\
\text { senior } \\
\text { housing, } \\
\text { and } \\
\text { churches } \\
\text { U.S. }\end{array}$ & $\begin{array}{l}\text { - } 1 \text { group pretest } \\
\text { and posttest design } \\
\text { - } 6 \text { week CDSMP, } \\
\text { adapted for } \\
\text { African American } \\
\text { population, } \\
\text { - Lay leader from } \\
\text { community and } \\
\text { health professional } \\
\text { - Follow up at } 10 \\
\text { weeks and } \\
6 \text { months }\end{array}$ & $\begin{array}{l}\text { - } \mathrm{N}=153 \\
\text { - } 86 \% \text { African } \\
\quad \text { American } \\
\text { - Mean Age: } 72 \\
\text { - } 82 \% \text { female } \\
\text { - Education } 11.5 \\
\text { years } \\
\text { - Heterogeneous } \\
\text { Disease Sample } \\
\text { - } \\
\text { - }\end{array}$ & $\begin{array}{l}\text { - Demographics } \\
\text { - Health Status } \\
\text { - Health Service } \\
\text { Utilization } \\
\text { - Health Behavior } \\
\text { - Perceived } \\
\text { self-efficacy } \\
\text { - Chronic Disease } \\
\text { Impact } \\
\text { - (all previously } \\
\text { published validity } \\
\text { and reliability) }\end{array}$ & $\begin{array}{l}\text { - At } 10 \text { weeks: } \\
\text { - Health behaviors } \\
\text { showed a significant } \\
\text { increase in stretching } \\
\text { and strengthening } \\
(p=0.04) .6 \text { months } \\
(p=0.03) \\
\text { - Significant increase } \\
\text { in cognitive } \\
\text { symptom } \\
\text { management } \\
@ 10 \text { weeks } \\
(P=0.01) ; \\
6 \text { months not } \\
\text { significant } \\
\text { Improvement in } \\
\text { health status } \\
\text { variables, } \\
\text { but not significant } \\
\text { - No significant } \\
\text { improvement in } \\
\text { self-efficacy, } \\
\text { healthcare } \\
\text { utilization, or } \\
\text { illness intrusiveness }\end{array}$ & $\begin{array}{l}\text { • Interpretation: } \\
\text { Participants felt } \\
\text { needed more sessions. } \\
\text { Results suggest } \\
\text { potential benefit } \\
\text { in this population } \\
\text { - Limitations: } \\
\text { No control group or } \\
\text { randomization, } \\
\text { High attrition rate } \\
\text { in follow up data, } \\
\text { - Generalizability: } \\
\text { Cannot generalize the } \\
\text { findings to African } \\
\text { American Older Adults } \\
\text { due to small sample size, } \\
\text { volunteers could limit } \\
\text { generalizability }\end{array}$ & $2 \mathrm{~b}$ \\
\hline $\begin{array}{l}\text { Ersek } \\
\text { et al. } \\
(2008)\end{array}$ & $\begin{array}{l}\text { Determine the } \\
\text { efficacy of a } \\
\text { pain } \\
\text { self-management } \\
\text { support group } \\
\text { versus a } \\
\text { self-education } \\
\text { control group }\end{array}$ & $\begin{array}{l}\text { None stated } \\
\text { (CDSMP as } \\
\text { resource) }\end{array}$ & $\begin{array}{c}\text { Retirement } \\
\text { communities } \\
\text { U.S. }\end{array}$ & $\begin{array}{l}\text { - Clustered RCT } \\
\text {-baseline measured } \\
\text { prior to randomiza- } \\
\text { tion, assessed after } \\
\text { intervention and at } \\
\text { one year. } \\
\text { - Pain } \\
\text { Self-Management } \\
\text { Group: } 7 \text { weekly } \\
\text { sessions } \\
\text { - Leaders were nurses } \\
\text { and psychologists }\end{array}$ & $\begin{array}{l} \\
\\
\text { - Randomized by } \\
\text { facility to control or } \\
\text { intervention group. } \\
\text { - N = 255 } \\
\text { - Mean Age } 82 \text { years } \\
\text { - } 87 \% \text { female } \\
\text { - } 73 \% \text { Caucasian } \\
\text { post-secondary } \\
\text { education } \\
\text { - Diagnosed with } \\
\text { arthritis } \\
\end{array}$ & $\begin{array}{l}\text { - Demographics } \\
\text { - Physical Disability: } \\
\text { Roland Morris } \\
\text { Disability } \\
\text { Questionnaire } \\
\text { (Validity/reliability } \\
\text { and responsiveness } \\
\text { to change } \\
\text { addressed) } \\
\text { - Pain intensity and } \\
\text { interference: Brief } \\
\text { Pain Inventory } \\
\text { (reliability and } \\
\text { validity stated) } \\
\text { - Self-efficacy: } \\
\text { Arthritis Efficacy } \\
\text { Scale (internal } \\
\text { consistency and test } \\
\text {-retest reliability) } \\
\text { - Catastrophizing: } \\
\text { Coping strategy } \\
\text { questionnaire } \\
\text { (validity and } \\
\text { reliability in } \\
\text { older adults stated) } \\
\text {-Coping: Chronic } \\
\text { Pain Coping } \\
\text { Inventory } \\
\text { (acceptable } \\
\text { internal } \\
\text { consistency and } \\
\text { test-retest } \\
\text { reliability) }\end{array}$ & $\begin{array}{l}\text { - In self-management } \\
\text { group coping } \\
\text { increased } \\
\text { significantly over } \\
\text { control group at } \\
\text { post intervention } \\
\text { and decrease } \\
\text { in } 1 \text { year } \\
\text { - No significant } \\
\text { change in } \\
\text { medication use in } \\
\text { either group at } \\
\text { post intervention } \\
\text { or } 1 \text { year. } \\
\text { - Slight decrease in } \\
\text { pain and disability } \\
\text { at } 6 \text { months with a } \\
12 \% \text { increase in } \\
\text { pain in intervention } \\
\text { group versus a } 19 \% \\
\text { increase in the } \\
\text { control group } \\
\text { at } 1 \text { year. } \\
\text { - Exercise (0.03) } \\
\text { and relaxation } \\
\text { (0.003) were only } \\
\text { outcomes with } \\
\text { statistical } \\
\text { significance }\end{array}$ & $\begin{array}{l}\text { Interpretation: } \\
\text { Self-management may } \\
\text { not be effective for } \\
\text { all types of chronic } \\
\text { disease. The overall } \\
\text { study showed little } \\
\text { effect between the } \\
\text { self-management } \\
\text { group and the } \\
\text { study group. } \\
\text { Recommendations for } \\
\text { further studies } \\
\text { evaluate effectiveness } \\
\text { Limitations: } \\
\text { not addressed, } \\
\text { Self-report } \\
\text { Generalizability: } \\
\text { Cannot be generalized, } \\
\text { volunteers could limit } \\
\text { generalizability }\end{array}$ & $1 b$ \\
\hline
\end{tabular}




\section{Continued}

\begin{tabular}{|c|c|c|c|c|c|c|c|c|c|}
\hline $\begin{array}{l}\text { Gitlin } \\
\text { et al. } \\
\text { (2008) }\end{array}$ & $\begin{array}{l}\text { Test } \\
\text { effectiveness } \\
\text { of translating the } \\
\text { CDSMP to } \\
\text { African } \\
\text { American } \\
\text { Seniors }\end{array}$ & $\begin{array}{l}\text { Self-Efficacy } \\
\text { Theory and } \\
\text { Translational } \\
\text { Theory }\end{array}$ & $\begin{array}{l}\text { Senior } \\
\text { Centers, } \\
\text { Churches, } \\
\text { community } \\
\text { centers } \\
\text { U.S. }\end{array}$ & $\begin{array}{l}\text { - Pre-post design } \\
\text { - Lay leaders retired } \\
\text { community } \\
\text { member (1 nurse) } \\
\text { 6-week course, } \\
\text { met weekly }\end{array}$ & $\begin{aligned} & \\
& \text { - } \mathrm{N}=519 \\
& \text { - African American } \\
& \text { - Mean Age:73 years } \\
& \text { - } 86 \% \text { Female } \\
& \text { - Heterogeneous } \\
& \text { Disease population } \\
& \text { - Education level } \\
& 41 \% \text { High School } \\
& \text { - } 44 \% \text { Secondary } \\
& \text { Education } \\
& \text { - Average had } 3 \\
& \text { chronic conditions } \\
& \text { - Heterogeneous } \\
& \text { Disease Sample } \\
&\end{aligned}$ & $\begin{array}{l}\text { - Measured outcomes } \\
\text { from CDSMP at } 4 \\
\text { months: } \\
\text { - Physical Activity } \\
\text { - Cognitive } \\
\text { Symptom } \\
\text { management } \\
\text { - Health Status } \\
\text { - Communication } \\
\text { - with Providers } \\
\text { - Health distress } \\
\text { - Health care } \\
\text { utilization } \\
\text { - Illness } \\
\text { intrusiveness } \\
\text { - Self-Efficacy } \\
\text { - Validity and } \\
\text { Reliability } \\
\text { addressed }\end{array}$ & $\begin{array}{l}\text { - Small statistical } \\
\text { significance in } \\
\text { cognitive } \\
\text { symptoms } \\
\text { management } \\
(p=0.01), \\
\text { self-efficacy } \\
(p=0.001) \text {, health } \\
\text { distress }(0.001), \\
\text { exercise }(p=0.001) \\
\text { - No change in } \\
\text { healthcare } \\
\text { utilization }\end{array}$ & $\begin{array}{l}\text { Interpretation: } \\
\text { Translates to the } \\
\text { African American } \\
\text { Population. Results adapt } \\
\text { for lower levels of } \\
\text { education and rename to } \\
\text { give historical and } \\
\text { biblical significance } \\
\text { Future Research needed } \\
\text { to see if booster sessions } \\
\text { would increase effect. } \\
\text { Limitations: } \\
\text { not reported, Volunteers, } \\
\text { Self-report } \\
\text { Generalizability: } \\
\text { to African American } \\
\text { Population, } \\
\text { volunteers could } \\
\text { limit generalizability }\end{array}$ & $2 \mathrm{~b}$ \\
\hline $\begin{array}{l}\text { Harvey, } \\
\text { P.W., } \\
\text { et al. (2008) }\end{array}$ & $\begin{array}{c}\text { Test a } \\
\text { structured } \\
\text { care plan version } \\
\text { of the CDSMP }\end{array}$ & $\begin{array}{l}\text { None } \\
\text { Stated }\end{array}$ & $\begin{array}{l}\text { Primary } \\
\text { Care } \\
\text { Harvey }\end{array}$ & $\begin{array}{l}\text { - Mixed method, } \\
\text { longitudinal study } \\
\text { Initial care } \\
\text { planning session } \\
\text { and then group } \\
\text { participation } \\
\text { in CDSMP } \\
\text { - Measured at } \\
\text { baseline and } 6 \\
\text { months }\end{array}$ & $\begin{array}{l}\text { - } \mathrm{N}=175 \\
\text { - } \text { Mean Age } 68 \\
\text { - } 61 \% \text { Female } \\
\text { - } \text { Aboriginal and } \\
\text { non-Aboriginal } \\
\text { sample } \\
\text { - Heterogeneous } \\
\text { disease mix }\end{array}$ & $\begin{array}{l}\text { Measured Partners } \\
\text { in Health survey } \\
\text { and Stanford } \\
2000 \text { Health } \\
\text { Survey }\end{array}$ & $\begin{array}{l}\text { Positive change } \\
\text { in outcomes, } \\
\text { healthcare } \\
\text { utilization, and } \\
\text { pain management }\end{array}$ & $\begin{array}{l}\text { Interpretation: } \\
\text { Small effect sizes suggest } \\
\text { that program has positive } \\
\text { effect on sample. } \\
\text { Limitations: } \\
\text { Small sample size, } \\
\text { Lack of control Group } \\
\text { Generalizability: } \\
\text { Due to convenience } \\
\text { sample and small sample } \\
\text { size, cannot be generalized. }\end{array}$ & $2 \mathrm{~b}$ \\
\hline $\begin{array}{l}\text { Klug } \\
\text { et al. } \\
\text { (2008) }\end{array}$ & $\begin{array}{l}\text { Describe the } \\
\text { feasibility and } \\
\text { outcomes in a } \\
\text { diabetes } \\
\text { self-management } \\
\text { program }\end{array}$ & $\begin{array}{l}\text { None } \\
\text { Stated }\end{array}$ & $\begin{array}{c}\text { Urban and } \\
\text { suburban } \\
\text { community } \\
\text { centers, weekly } \\
\text { meetings } \\
\text { Lay leaders } \\
\text { of similar } \\
\text { characteristics, } \\
\text { known and } \\
\text { respected in } \\
\text { community U.S. }\end{array}$ & $\begin{array}{l}\text { Mixed method, } \\
\text { pre and post } \\
\text { data collection } \\
\text { 6-month } \\
\text { pilot study } \\
\end{array}$ & $\begin{array}{l}\text { - } \mathrm{N}=144 \\
\text { - } \text { Mean Age: } 69 \\
\text { - } 24 \% \text { non-Caucasian } \\
\text { - } 81 \% \text { female } \\
\text { - Education: } 60 \% \\
\text { High School } \\
\text { or Less } \\
\text { - Diagnosed with } \\
\text { Type II Diabetes }\end{array}$ & $\begin{array}{l}\text { - -Demographics } \\
\text { - -Diet and physical } \\
\text { activity changed } \\
\text { - -Self-efficacy } \\
\text { - -Community } \\
\text { Resources using } \\
\text { the Chronic Illness } \\
\text { Resources Survey } \\
\text { - (Validity and } \\
\text { Reliability not } \\
\text { addressed } \\
\text { by author) }\end{array}$ & $\begin{array}{l}\text { - Related length of } \\
\text { disease and } \\
\text { increased } \\
\text { self-efficacy } \\
(P=0.017) \\
\text { predictors of } \\
\text { change } \\
\text { - Self-rated health } \\
\text { (P.001) did } \\
\text { not meet previously } \\
\text { documented levels in } \\
\text { CDSMP } \\
\text { - CIRS results not } \\
\text { discussed }\end{array}$ & $\begin{array}{l}\text { Interpretation: } \\
\text { Identified gap of } \\
\text { community based diabetes } \\
\text { resources for older } \\
\text { adult. Barriers to attending: } \\
\text { transportation, inconvenient } \\
\text { location and times } \\
\text { Limitations: } \\
\text { Lacked control group, } \\
\text { self-report measures } \\
\text { in assessing outcomes, } \\
\text { difficulty in obtaining } \\
\text { resources for class, } 4 \\
\text { month survey participation } \\
\text { declined sharply } \\
\text { Generalizability: } \\
\text { Need further research } \\
\text { to identify suitable program } \\
\text { length, increased goal } \\
\text { attainment work in } \\
\text { program, small sample } \\
\text { size unable to determine } \\
\text { generalizability, } \\
\text { volunteers could } \\
\text { limit generalizability }\end{array}$ & $2 \mathrm{~b}$ \\
\hline $\begin{array}{l}\text { LaForest } \\
\text { et al. } \\
(2008)\end{array}$ & $\begin{array}{l}\text { Evaluation of } \\
\text { adapted CDSMP } \\
\text { on homebound } \\
\text { frail older } \\
\text { adults with } \\
\text { arthritis }\end{array}$ & $\begin{array}{l}\text { Social } \\
\text { Cognitive } \\
\text { Theory }\end{array}$ & $\begin{array}{c}6 \text { weekly } 1 \\
\text { hour visits to } \\
\text { homebound } \\
\text { U.S. } \\
\text { Lay leaders } \\
\text { all healthcare } \\
\text { providers }\end{array}$ & $\begin{array}{l}\text { - Randomized, expe- } \\
\text { rimental design } \\
\text { - Measurements at } \\
\text { screening, imme- } \\
\text { diately } \\
\text { pre-intervention, } \\
\text { immediately post } \\
\text { intervention, and at } 8 \\
\text { weeks }\end{array}$ & $\begin{array}{l}\text { - Randomly assigned } \\
\text { to control group and } \\
\text { intervention group. } \\
\text { - } \mathrm{N}=125 \\
\text { - Control group } \\
\text { mean age: } 77 \\
\text { (91\% female) } \\
\text { - Intervention group } \\
\text { mean age: } 78 \\
\text { (90\% female) } \\
\text { - Ethnicity not } \\
\text { 8eported } \\
\text { - } 19 \% \text { perceived low } \\
\text { income, } \\
\text { - Education: } 9 \text { years } \\
\text { of education } \\
\text { - Diagnosed with } \\
\text { arthritis }\end{array}$ & $\begin{array}{l}\text { - Demographics } \\
\text { - Health Activities: } \\
\text { - Physical } \\
\text { (Cronbach's } \\
\text { alpha 0.77) or } \\
\text { Social (Cronbach's } \\
\text { alpha 0.74) } \\
\text { - Pain } \\
\text { - Stiffness } \\
\text { - Fatigue } \\
\text { - Functional } \\
\text { limitations } \\
\text { - Helplessness } \\
\text { - Coping } \\
\text { Effectiveness } \\
\text { - Self-efficacy: } \\
\text { Arthritis-Self- } \\
\text { Efficacy Scale } \\
\text { - (Validity and } \\
\text { reliability } \\
\text { previously } \\
\text { established) } \\
\text { - Outcome } \\
\text { expectations of } \\
\text { program were } \\
\text { measured with } \\
\text { using developed } \\
\text { self-report } \\
\text { questions } \\
\text { (Cronbach's } \\
\text { alpha .58) }\end{array}$ & $\begin{array}{l}\text { - Statistically } \\
\text { significant decrease } \\
\text { in functional } \\
\text { limitation }(P=0.04) \\
\text { - Helplessness } \\
\text { decrease }(P=0.05) \\
\text { - -Other variables } \\
\text { not statistically } \\
\text { significant }\end{array}$ & $\begin{array}{l}\text { Interpretation: } \\
\text { Those that had the } \\
\text { greatest change in } \\
\text { physical health } \\
\text { behaviors and outcome } \\
\text { expectations had } \\
\text { greater benefits from } \\
\text { the program although the } \\
\text { effect on pain, stiffness, } \\
\text { and fatigue were minimal. } \\
\text { Self-efficacy did not have } \\
\text { the biggest effect as a } \\
\text { moderator, but outcome } \\
\text { expectations were more } \\
\text { predictive. } \\
\text { Limitations: } \\
\text { Self-reported data, low } \\
\text { instrument reliability, } \\
\text { small sample size } \\
\text { Generalizability: } \\
\text { not generalizable to } \\
\text { frail adults as a } \\
\text { whole, volunteers } \\
\text { could limit } \\
\text { generalizability }\end{array}$ & $1 \mathrm{~b}$ \\
\hline
\end{tabular}




\section{Continued}

\begin{tabular}{|c|c|c|c|c|c|c|c|c|c|}
\hline $\begin{array}{c}\text { Speer, } \\
\text { M.S. } \\
\text { et al. (2008) }\end{array}$ & $\begin{array}{l}\text { Compare the } \\
\text { effects of a } \\
\text { statewide } \\
\text { diabetic } \\
\text { intervention } \\
\text { program }\end{array}$ & $\begin{array}{l}\text { None } \\
\text { stated }\end{array}$ & $\begin{array}{c}\text { Senior } \\
\text { Centers } \\
\text { U.S. } \\
\text { (Georgia) }\end{array}$ & Pre-post design & $\begin{array}{l}\text { - } \mathrm{N}=351 \\
\text { - } 55 \% \text { Black } \\
\text { - } 84 \% \text { Female } \\
\text { - } \text { Mean Age } 77 \\
\text { - } \text { Mean education = } \\
11 \text { years } \\
\text { - } \text { Diabetic sample }\end{array}$ & $\begin{array}{l}\text { - Diabetes Self-Care } \\
\text { Activities } \\
\text { (Toobert) } \\
\text { - Demographics, } \\
\text { weight, BMI, } \\
\text { HgbA1C }\end{array}$ & $\begin{array}{l}\text { Significant decrease } \\
\text { in hemoglobin A1C } \\
(1 \%) \text {. Increased } \\
\text { participation in } \\
\text { self-care behaviors. }\end{array}$ & $\begin{array}{c}\text { Self-report } \\
\text { instrument, } \\
\text { self-report pretest } \\
\text { HgbA1C and weight, } \\
\text { variability in } \\
\text { implementation across } \\
\text { state, no control group, } \\
\text { convenience sample. } \\
\text { Generalizability: } \\
\text { Cannot be generalized }\end{array}$ & \\
\hline $\begin{array}{l}\text { Swerissen } \\
\text { et al. } \\
(2006)\end{array}$ & $\begin{array}{l}\text { To determine if } \\
\text { the use of the } \\
\text { CDSMP in } \\
\text { culturally and } \\
\text { linguistically } \\
\text { diverse cultures } \\
\text { will improve } \\
\text { health outcomes, } \\
\text { satisfaction, } \\
\text { and decrease } \\
\text { health care } \\
\text { utilization }\end{array}$ & $\begin{array}{c}\text { Social } \\
\text { Learning } \\
\text { Theory }\end{array}$ & $\begin{array}{l}\text { Community } \\
\text { setting such as } \\
\text { senior centers, } \\
\text { churches, and } \\
\text { community } \\
\text { health centers } \\
\text { Peer leaders }\end{array}$ & $\begin{array}{l}\text { - RCT } \\
6 \text { weekly sessions, } \\
\text { delivered in native } \\
\text { language } \\
\text { - Data collected at } \\
\text { baseline and then } \\
\text { monthly for } 6 \\
\text { months }\end{array}$ & $\begin{array}{l}\text { - Stratified by } \\
\text { language and area; } \\
\text { randomized to } \\
\text { intervention or } \\
\text { wait-list } \\
\text { - Greek, } \\
\text { Vietnamese, } \\
\text { Italian, Chinese } \\
\text { (control and } \\
\text { intervention group } \\
\text { in each language) } \\
\text { - Mean age: } 60 \text { - } 68 \\
\text { - Female: } 63 \% \\
\text { - Education mean } \\
\text { years }<11 \text { in all } \\
\text { groups } \\
\text { - Heterogeneous } \\
\text { diseases, and mul- } \\
\text { tiple chronic condi- } \\
\text { tions, }\end{array}$ & $\begin{array}{l}\text { - Demographics } \\
\text { - Health Status } \\
\text { - Health Behaviors } \\
\text { - Self-Efficacy } \\
\text { - Health Service } \\
\text { Utilization } \\
\text { - (Previous } \\
\text { reliability and } \\
\text { validity } \\
\text { established) }\end{array}$ & $\begin{array}{l}\text { - Significant increase } \\
\text { in health behaviors } \\
\text { in the intervention } \\
\text { group } \\
\text { - Health distress } \\
(P<0.001) \\
\text { - Activity limitation } \\
(P=0.002) \\
\text { - Self-efficacy } \\
(P=0.000) \\
\text { - Cognitive } \\
\text { symptom }(P=0.001) \\
\text { - Pain }(P=0.019) \\
\text { - Fatigue }(P=0.01) \\
\text { - Depression } \\
\text { ( } P=0.041) \\
\text { - Illness intrusiveness } \\
(P=0.044) \\
\text { - Self-rated health } \\
\text { ( } P=0.025) \\
\text { - No difference } \\
\text { between two groups } \\
\text { in disability scale, or } \\
\text { social limitation, } \\
\text { - No difference in } \\
\text { healthcare } \\
\text { utilization (already } \\
\text { low at baseline) }\end{array}$ & $\begin{array}{l}\text { Interpretations: } \\
\text { Overall positive health } \\
\text { outcomes. } \\
\text { Need referral process } \\
\text { so that the population } \\
\text { with the most } \\
\text { need is reached. } \\
\text { Limitations: } \\
\text { The subjects were } \\
\text { volunteers and not } \\
\text { referred indicating a } \\
\text { higher motivation. } \\
\text { Wait-list method } \\
\text { affected long-term } \\
\text { comparison in groups. } \\
\text { Recommend further } \\
\text { research in different } \\
\text { cultures and languages to } \\
\text { determine the effectiveness. } \\
\text { Generalizability: } \\
\text { Can only be generalized } \\
\text { to the Australian } \\
\text { of the language tested } \\
\text { in the study, } \\
\text { volunteers could limit } \\
\text { generalizability }\end{array}$ & $1 \mathrm{~b}$ \\
\hline $\begin{array}{l}\text { Hass } \\
\text { et al. } \\
\text { (2005) }\end{array}$ & $\begin{array}{l}\text { Evaluate the } \\
\text { effectiveness of } \\
\text { chronic disease } \\
\text { self-management } \\
\text { (CDSMP)in older } \\
\text { adults with low } \\
\text { back pain }\end{array}$ & $\begin{array}{l}\text { None } \\
\text { stated }\end{array}$ & $\begin{array}{c}\text { Community } \\
\text { based sites } \\
\text { (YW/YMCA's, } \\
\text { churches, senior } \\
\text { center) } \\
\text { Australia } \\
\text { (Greek, } \\
\text { Vietnamese, } \\
\text { Chines, and } \\
\text { Italian) }\end{array}$ & $\begin{array}{l}\text { - Prospective, Parallel, } \\
\text { RCT } \\
\text { Intervention versus } 6 \\
\text { month wait list } \\
\text { - Including phone call } \\
\text { every two weeks }\end{array}$ & $\begin{array}{l}\text { - } \mathrm{N}=120 \\
(11 \text { dropout }) \\
\text { - IG = 60 } \\
\text { - Waitlist = 60 } \\
\text { - } 84 \% \text { Female } \\
\text { - } 14.7 \% \text { African } \\
\text { American } \\
\text { - Education: } 95 \% \\
\text { high school, } \\
24 \% \text { of those had } \\
\text { college } \\
\text { - Arthritis/Low } \\
\text { back pain }\end{array}$ & $\begin{array}{l}\text { - Demographics } \\
\text { - Pain } \\
\text { - Disability } \\
\text { - Disease } \\
\text { Interference } \\
\text { - Perceived } \\
\text { Self-efficacy } \\
\text { - Attitudes towards } \\
\text { Self-health } \\
\text { - General health } \\
\text { rating } \\
\text { - (Scale validity } \\
\text { and reliability } \\
\text { addressed) }\end{array}$ & $\begin{array}{l}\text { - } 6 \text { month: no } \\
\text { difference between } \\
\text { two groups in pain } \\
\text { rating, functional } \\
\text { disability, days of } \\
\text { back pain. } \\
\text { No statistical } \\
\text { difference } \\
\text { between groups in } \\
\text { self-efficacy or } \\
\text { health attitude } \\
\text { - Baseline comparison } \\
\text { in IG: statistically } \\
\text { significant for } \\
\text { disability }(0.007) \\
\text { days and emotional } \\
\text { well-being }(0.037)\end{array}$ & $\begin{array}{l}\text { Interpretations: } \\
\text { CDSM had little } \\
\text { advantage of routine } \\
\text { care in those } \\
\text { with low back pain } \\
\text { Limitations: } \\
\text { participants refused } \\
\text { randomization. } \\
\text { Lack of participation } \\
\text { by seniors in phone } \\
\text { calls, self-report scales, } \\
\text { lack of recruitment, } \\
\text { cannot follow-up } \\
\text { long-term due to design } \\
\text { Generalizability: } \\
\text { Small sample size, } \\
\text { unable to generalize to } \\
\text { population. volunteers } \\
\text { could limit } \\
\text { generalizability }\end{array}$ & $1 \mathrm{~b}$ \\
\hline
\end{tabular}




\section{Continued}

\begin{tabular}{|c|c|c|c|c|c|c|c|c|c|}
\hline $\begin{array}{l}\text { Lorig } \\
\text { et al. } \\
\text { (2005) }\end{array}$ & $\begin{array}{c}\text { Compare } \\
\text { disease specific } \\
\text { self-management } \\
\text { (ASMP) versus } \\
\text { generic } \\
\text { self-management } \\
\text { (CDSMP) }\end{array}$ & $\begin{array}{l}\text { Self-efficacy } \\
\text { theory }\end{array}$ & $\begin{array}{l}\text { Community } \\
\text { centers } \\
\text { U.S. }\end{array}$ & $\begin{array}{l}\text { - RCT } \\
\text { - Randomized to } \\
\text { either disease } \\
\text { specific (ASMP) or } \\
\text { Generic (CDSMP) } \\
\text { - Data Collected at } \\
\text { baseline, } 4 \text { months, } \\
\text { and } 12 \text { months }\end{array}$ & $\begin{array}{l}\text { - ASMP = } 239 \\
\text { - } \text { CDSMP = } 116 \\
\text { - Mean age = } 65 \\
\text { - Years of Education } \\
=16 \\
\text { - Female: ASMP } 81 \% \\
\text { - CDSMP: } 78 \% \\
\text { - Diagnosed with } \\
\text { Arthritis } \\
\text { - }\end{array}$ & $\begin{array}{l}\text { - Demographics } \\
\text { - Health Distress } \\
\text { - -Self-reported } \\
\text { - Global Health } \\
\text { - Activity Limitation } \\
\text { - - Disability } \\
\text { - Fatigue } \\
\text { - Pain } \\
\text { - - Aerobic Exercise } \\
\text { - Stretching and } \\
\text { - Selfengthening } \\
\text { - Physician Visits } \\
\text { - Hospitalizations } \\
\text { - -Validity and } \\
\text { Reliability } \\
\text { Addressed }\end{array}$ & $\begin{array}{l}\text { - Improvement in } \\
\text { individual groups } \\
\text { compared to baseline } \\
\text { 4-month: ASMP } \\
\text { demonstrated } \\
\text { greater improvement } \\
\text { in health distress, } \\
\text { activity limitation, } \\
\text { and fatigue } \\
\text { 1 year: ASMP had } \\
\text { significant } \\
\text { improvements in } \\
\text { health distress, } \\
\text { activity limitation, } \\
\text { disability, fatigue, } \\
\text { pain, practice mental } \\
\text { stress management, } \\
\text { stretching and } \\
\text { strengthening, and } \\
\text { self-efficacy }\end{array}$ & $\begin{array}{c}\text { Interpretations: } \\
\text { ASMP has advantages } \\
\text { compared to CDSMP, } \\
\text { lessening slightly at } 1 \text { year } \\
\text { Limitations: } \\
\text { CDSMP enrollment } \\
\text { half of ASMP, } \\
\text { Self-report } \\
\text { Recommendations: As } \\
\text { chronic diseases are different } \\
\text { need to study other disease } \\
\text { specific groups to see if } \\
\text { positive effects are achieved } \\
\text { versus the CDSMP } \\
\text { Generalizability: } \\
\text { Not addressed, adequate } \\
\text { power for sample size. } \\
\text { volunteers could limit } \\
\text { generalizability }\end{array}$ & $1 \mathrm{~b}$ \\
\hline $\begin{array}{l}\text { Farrell } \\
\text { et al. } \\
(2004)\end{array}$ & $\begin{array}{l}\text { To evaluate the } \\
\text { effectiveness } \\
\text { and acceptability } \\
\text { of the CDSMP in } \\
\text { the underserved, } \\
\text { poor, rural, } \\
\text { predominantly } \\
\text { African } \\
\text { American } \\
\text { population (pilot) }\end{array}$ & $\begin{array}{c}\text { Self-Efficacy } \\
\text { Theory } \\
\text { CDSMP }\end{array}$ & $\begin{array}{c}\text { Rural, } \\
\text { underserved, } \\
\text { socioeconomi- } \\
\text { cally declined } \\
\text { Clinic } \\
\text { U.S. }\end{array}$ & $\begin{array}{l}\text { - Quasi-experimental, } \\
\text { pre-post design } \\
\text { - 6-week intervention } \\
\text { - Lay leaders from } \\
\text { community }\end{array}$ & $\begin{array}{l}\text { - } \mathrm{N}=48 \\
\text { - } 79 \% \text { Caucasian } \\
\text { - } 81 \% \text { women } \\
\text { - Mean Age: } 60 \\
\text { - Education Mean: } 12 \\
\text { years } \\
\text { - Heterogeneous } \\
\text { chronic diseases }\end{array}$ & $\begin{array}{l}\text { - Demographics } \\
\text { - Self-efficacy: } \\
\text { Self-Efficacy } \\
\text { Cantril Ladder } \\
\text { (face and content } \\
\text { validity) } \\
\text { - CDSMP validated } \\
\text { and reliable } \\
\text { testing done } \\
\text { previously for } \\
\text { instruments } \\
\text { used for } \\
\text { - Health behaviors } \\
\text { - Symptom } \\
\text { management } \\
\text { - Communication } \\
\text { Provider }\end{array}$ & $\begin{array}{l}\text { Improvement in all } \\
\text { measurements noted, } \\
\text { but only self-efficacy } \\
(P=0.01) \\
\text { cognitive symptom } \\
\text { management } \\
(P=0.10 \text { were } \\
\text { significant } \\
\text { immediately } \\
\text { after intervention }\end{array}$ & $\begin{array}{l}\text { Interpretation: } \\
\text { All findings consistent } \\
\text { with previous studies of } \\
\text { similar populations except } \\
\text { for exercise being slightly } \\
\text { increased which is not } \\
\text { normally seen. Possibly } \\
\text { due to location or timing } \\
\text { of study. } \\
\text { Limitations: } \\
\text { heterogeneous patient mix, } \\
\text { lack of comparison group } \\
\text { with usual care, } \\
\text { short-term follow-up, } \\
\text { pre-post design, and } \\
\text { convenience sampling. } \\
\text { Generalizability: } \\
\text { Small sample size unable } \\
\text { to generalize to population, } \\
\text { volunteers could limit } \\
\text { generalizability }\end{array}$ & $2 b$ \\
\hline $\begin{array}{c}\text { Lori, K.R. } \\
\text { et al. } \\
\text { (2001) }\end{array}$ & $\begin{array}{l}\text { To assess the } 1 \\
\text { year and 2-year } \\
\text { effect of the } \\
\text { CDSMP on health } \\
\text { status, } \\
\text { self-efficacy } \\
\text { and healthcare } \\
\text { utilization }\end{array}$ & $\begin{array}{l}\text { Self-Efficacy } \\
\text { Theory }\end{array}$ & $\begin{array}{c}\text { Community } \\
\text { U.S. }\end{array}$ & $\begin{array}{l}\text { - Longitudinal } \\
\text { follow-up to } \\
\text { RCT-2 year } \\
\text { - Lay leaders, } \\
\text { observational } \\
\text { education }\end{array}$ & $\begin{array}{l}\text { - Randomized } \\
\text { sample with } \\
\text { wait list rotation } \\
\text { into program. } \\
\text { - } \mathrm{N}=683 \\
\text { - Mean age: } 65.3 \\
\text { - } 64 \% \text { female } \\
\text { - } 90 \% \text { Caucasian } \\
\text { - Education: } 15 \text { years } \\
\text { - Heterogeneous } \\
\text { Disease Sample }\end{array}$ & $\begin{array}{l}\text { - Demographics } \\
\text { - Health Status } \\
\text { - Healthcare Utiliza- } \\
\text { tion } \\
\text { - Perceived } \\
\text { Self-Efficacy } \\
\text { - Discussion of } \\
\text { validation of newly } \\
\text { validated tools } \\
\text { provided. }\end{array}$ & $\begin{array}{l}\text { - At } 1 \text { and } 2 \text { year, } \\
\text { decreased healthcare } \\
\text { utilization }(0.006) \text {, } \\
\text { health distress } \\
(0.0001) \text { and } \\
\text { increased } \\
\text { self-efficacy } \\
(0.0001) \\
\text { - All other measures } \\
\text { were not significant }\end{array}$ & $\begin{array}{l}\text { Interpretation: } \\
\text { Findings support the } \\
\text { use of the } 7 \text { week program } \\
\text { to decrease hospital } \\
\text { visits and health distress. } \\
\text { Participants with } 2 \\
\text { chronic diseases did not } \\
\text { show deterioration } \\
\text { during the study period. } \\
\text { Limitations: } \\
\text { to interpreting findings: } \\
\text { Dropout rate, lack of } \\
\text { control group due to wait } \\
\text { list method design so true } \\
\text { comparison not a } \\
\text { possibility } \\
\text { Generalizability: } \\
\text { Based on these results } \\
\text { and previous studies } \\
\text { recommend tertiary } \\
\text { implementation of } \\
\text { CDSMP/volunteers could } \\
\text { limit generalizability }\end{array}$ & $1 \mathrm{~b}$ \\
\hline $\begin{array}{l}\text { Lorig } \\
\text { et al. } \\
\text { (1999) }\end{array}$ & $\begin{array}{c}\text { Explore the } \\
\text { effectiveness of } \\
\text { a chronic disease } \\
\text { self-management } \\
\text { program with a } \\
\text { heterogeneous } \\
\text { group of chronic } \\
\text { disease patients }\end{array}$ & $\begin{array}{l}\text { Self-Efficacy } \\
\text { Theory }\end{array}$ & $\begin{array}{c}\text { Community } \\
\text { based sites } \\
\text { U.S. }\end{array}$ & $\begin{array}{l}\text { - } 6 \text { month RCT, } \\
\text { wait-list control } \\
\text { subjects, } \\
\text { - Intervention } \\
\text { including } \\
\text { role-modeling, } \\
\text { feedback, and goal } \\
\text { setting, } 7 \text { weekly } \\
\text { sessions, lay } \\
\text { leaders, } \\
\text { small classes }\end{array}$ & $\begin{array}{l}\text { - Randomized } \\
\text { sample } \\
\text { - } \mathrm{N}=952 \\
\text { - Mean Age } \\
\text { Control: } 65 \\
\text { - Mean Age } \\
\text { Intervention: } \\
65.6 \\
\text { - } 64 \% \text { and } 65 \% \\
\text { female } \\
\text { respectively } \\
\text { - } 91 \% \text { Caucasian } \\
\text { - Average } 2.2 \\
\text { chronic disease } \\
\text { - Heterogeneous } \\
\text { Disease Sample }\end{array}$ & $\begin{array}{l}\text { - Demographics } \\
\text { - Health Status: } \\
\text { Self-rated-Health } \\
\text { Scale and } \\
\text { modified-Health } \\
\text { Assessment } \\
\text { Questionnaire } \\
\text { Disability Scale; } \\
\text { Medical Outcomes } \\
\text { Survey (MOS) } \\
\text { Pain Scale, MOS } \\
\text { distress scale, MOS } \\
\text { fatigue and energy } \\
\text { scale, } \\
\text { - Health Behaviors: } \\
\text { scales developed } \\
\text { for this study } \\
\text { - Healthcare } \\
\text { utilization: scales } \\
\text { developed for this } \\
\text { study } \\
\text { - Validity and } \\
\text { Reliability } \\
\text { discussed }\end{array}$ & $\begin{array}{l}\text { - At } 6 \text { months, } \\
\text { intervention group } \\
\text { had significant } \\
(p<0.05) \text { increased } \\
\text { exercise }(P=0.01) \text {, } \\
\text { improvement in } \\
\text { cognitive symptoms } \\
\text { management } \\
(P=0.01) \text {, } \\
\text { communication with } \\
\text { providers ( } P=0.01) \text {, } \\
\text { self-rated health, } \\
\text { fatigue, disability, } \\
\text { and social } \\
\text { limitations. ( } P=0.02) \\
\text { - Decrease in provider } \\
\text { visits and days in } \\
\text { hospital. } \\
\text { - Other indicators } \\
\text { were not significant }\end{array}$ & $\begin{array}{l}\text { Interpretation: } \\
\text { Based on the findings, } \\
\text { suggests that the individual } \\
\text { can be successfully used } \\
\text { with a heterogeneous } \\
\text { groups of diseases and } \\
\text { not disease specific. } \\
\text { Limitations: } \\
\text { Not all patients had same } \\
\text { symptoms and need same } \\
\text { changes in behavior. } \\
\text { Difficult to evaluate } \\
\text { homogeneously due to } \\
\text { comorbidities } \\
\text { Need replication to } \\
\text { determine effectiveness } \\
\text { of proposed program. } \\
\text { Generalizability: } \\
\text { generalizability limited } \\
\text { due to participants } \\
\text { volunteering for study } \\
\text { affecting motivation }\end{array}$ & $1 \mathrm{~b}$ \\
\hline
\end{tabular}

